\title{
Nitrification rates in the NW Mediterranean Sea
}

\author{
Micheline Bianchi ${ }^{1, *}$, Christine Fosset ${ }^{1}$, Pascal Conan ${ }^{2}$ \\ ${ }^{1}$ Laboratoire de Microbiologie Marine, CNRS/INSU UPR 223, Université de la Méditerranée, Campus de Luminy, Case 907 , \\ F-13288 Marseille Cedex 9, France \\ ${ }^{2}$ COM-LOB, Campus de Luminy, Case 901, F-13288 Marseille Cedex 9, France
}

\begin{abstract}
During spring, ammonium oxidation and nitrite oxidation rates were measured in the NW basin of the Mediterranean Sea, from mesotrophic sites (Ligurian Sea and Gulf of Lions) to oligotrophic sites (Balearic Islands). Nitrification rates (average values for 37 measurements) ranged from 72 to 144 nmol of $\mathrm{N}$ oxidised $\mathrm{l}^{-1} \mathrm{~d}^{-1}$, except in the Rhône River plume area where the rates increased to 264-504 $\mathrm{nmol} \mathrm{l}^{-1} \mathrm{~d}^{-1}$ because of the riverine inputs of nitrogen. Maximal rates were located around the peak of nitrite within the nitracline at about 40 to $60 \mathrm{~m}$ and just above the phosphacline. At 1 station, relatively high values of nitrification $\left(50\right.$ to $130 \mathrm{nmol} \mathrm{l}^{-1} \mathrm{~d}^{-1}$ ) were also measured deep in the water column $(240 \mathrm{~m})$. Day-to-day variations were measured demonstrating the response within a few hours to hydrological stress (wind-induced mixing of the water column) and showing the role of hydrological characteristics on the distribution of nitrification rates. Because of the homogenous temperature $\left(13^{\circ} \mathrm{C}\right)$ in the Mediterranean Sea, the spatial (geographical and vertical) fluctuations of nitrifying rates were linked to the presence of substrate due to mineralisation processes and/or Rhône River inputs. We estimate the contribution of nitrate produced by nitrification to the $\mathrm{N}$ demand of phytoplankton to range from $16 \%$ at mesotrophic to $61 \%$ at oligotrophic stations.
\end{abstract}

KEY WORDS: Mediterranean Sea $\cdot$ Nitrification $\cdot$ Spatial variability $\cdot$ Short-term fluctuation $\cdot \mathrm{N}$ budget

\section{INTRODUCTION}

The Mediterranean Sea is well known for its moderate oligotrophy (Berland et al. 1980, Jacques 1989) Atlantic surface water entering through the Strait of Gibraltar is nutrient-depleted, so nutrient loads depend on atmospheric and land inputs (Coste et al 1988, Cruzado \& Velasquez 1990, Bethoux et al. 1992). The Adriatic Sea and the NW basin (Gulf of Lions) are less oligotrophic due to the nutrient inputs of the Po and Rhône rivers. In the Gulf of Lions during the summer, areas not under direct influence of the Rhône but subjected to the NW Mediterranean Current can exhibit very low nutrient concentrations in the surface water. In this area, there is a strong nitracline between 50 and $100 \mathrm{~m}$ (Cruzado \& Velasquez 1990) and a phosphacline 0 to $40 \mathrm{~m}$ deeper (Berland et al. 1988, Conan 1996).

Over the past decade, research in the Mediterranean Sea has focused on biological processes determining nutrient budgets and fluxes in the photic layer (Minas

\footnotetext{
·E-mail: m-bianchi@luminy.univ-mrs.fr
}

et al. 1988). Study of one of the major biological processes of the nitrogen cycle, nitrification, has been neglected in the euphotic layer (Bianchi et al. 1994a, b, Gentilhomme \& Raimbault 1994), although in models the nitrate produced by nitrification sensu lato (in the deep layer) is taken into account via physical processes like diffusion and/or mixing. Most nitrification occurs at the bottom of the photic zone in the nitracline, leading to a rapid cycling of nitrogen to nitrate (Ward et al. 1989, Bianchi et al. 1994b). This regenerated nitrate is rapidly consumed by primary production (Gentilhomme 1992). The contribution of nitrification to nitrate uptake by primary producers constitutes a bias in nitrate-based measurement of new production as defined by Dugdale \& Goering (1967) that could increase with the increasing oligotrophy of the ecosystem.

In this paper, we attempt to assess the importance of nitrification in the NW Mediterranean. The spatial (vertical and horizontal) distribution of nitrification activities were estimated during spring (April, May and June 1995) in several areas from the Ligurian Sea and the Gulf of Lions to the Balearic Islands. Such 
extended geographical distribution was chosen to examine the relationship between the trophic status and nitrification rates. Short-term variations of nitrification rates were measured at $50 \mathrm{~m}$ depth at an oligotrophic station in the Ligurian Sea to study the impact of changes in the water column structure after wind mixing. Nitrification rates were compared to the input of nitrate in the photic layer by a vertical diffusive process in order to estimate the contribution of nitrification to the overall flux of nitrate.

\section{MATERIALS AND METHODS}

Overview of study. In the NW basin of the Mediterranean Sea, primary production displays a high geographical variability. The nutrient inputs from the Rhône River outflow play a major role in this geographical patchiness. For this reason, we sampled at 8 stations widely distributed in the NW basin (Fig. 1) to study the spatial distribution of nitrification. The stations were: Stn 1 in Ligurian Sea; Stns M1, M3, B2 and B5 in the Gulf of Lions; Stns S2 and S5 in the Balearic Island area; and Stn Rhône in the Rhône River plume (Fig. 1). All cruises were performed during spring (April, May and June 1995). Table 1 gives details of the

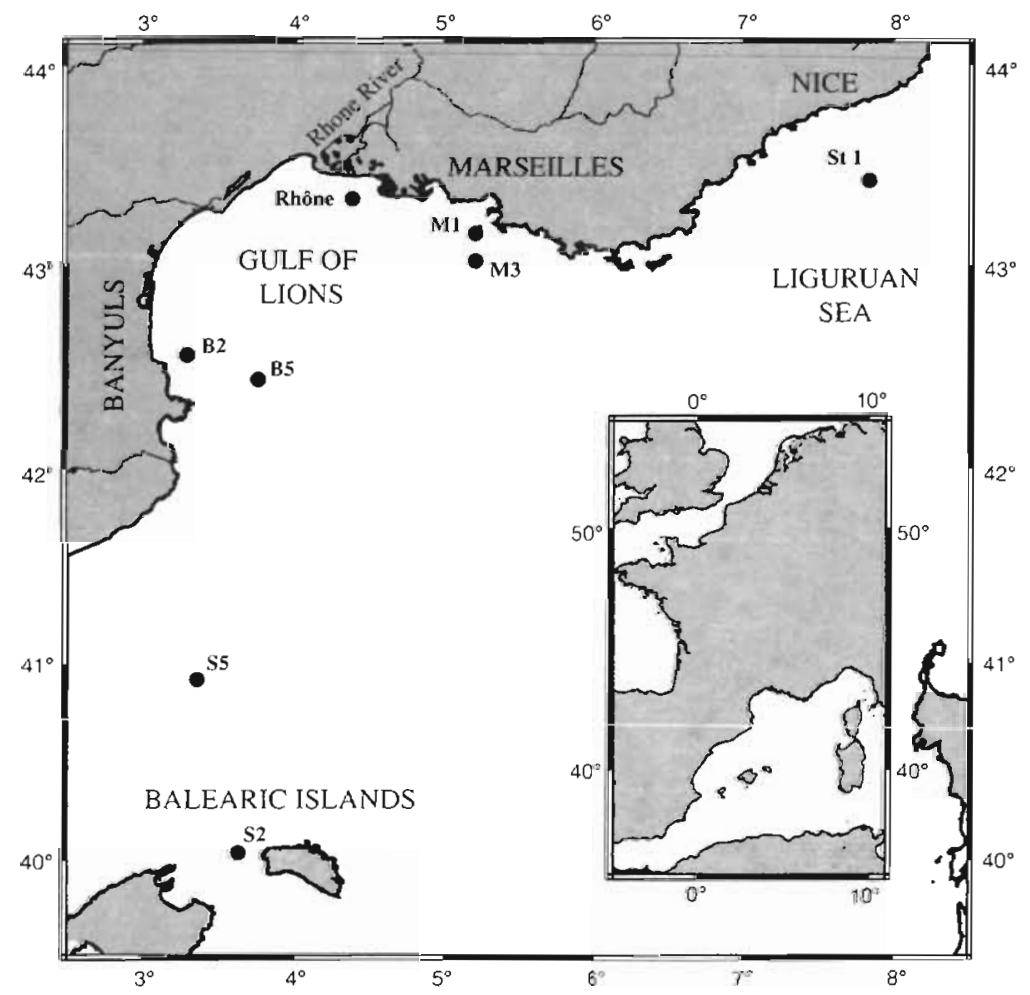

Fig. 1. Location of sampling stations. Stn 1 (Ligurian Sea: Picnic cruise and Dynaproc cruise), Stns M1, M3, B2 and B5 (Gulf of Lions: Euromarge cruise), Stns S2 and S5 (Balearic Islands: Euromarge cruise), Stn Rhone: Rhône plume area sampling: cruises, dates, locations and depths. Briefly, the geographical distribution of nitrification rates was assessed through 3 cruises: 'Picnic cruise' for Stn 1 , and 'Euromarge cruise' for Stns M1, M3, B2, B5, S2, S5. Both cruises were organised within the Mediterranean Targeted Project (E.C. MAST II Projects). During these cruises, the sampling depths were determined by considering the fluorescence profiles provided in real time by CTD casts. The third cruise, 'Rhône cruise', was devoted to the measurement of nitrification in the Rhône River plume. For this station, all samples were taken below the plume at $10 \mathrm{~m}$.

Short-term variations of nitrifying activity were measured during the Dynaproc cruise (Dyfamed French programme) in May at Stn 1 (Fig. 1). This cruise was designed to study the impact of short-term vertical processes induced by wind stress (Andersen et al. 1990). Samples were taken twice a day during 2 periods of measurements, during which time mixing of the water column was expected due to wind stress. The sampling depth was $50 \mathrm{~m}$, below the peak of in situ fluorescence located at $30 \mathrm{~m}$ depth.

Physical and chemical measurements. Temperature and in situ fluorescence were measured using a CTD probe (Seabird SBE 911+). For the Rhône plume samples, the temperature was measured using a YSI probe (Yellow Springs Instruments Co., Ohio, USA).

Nitrite, nitrate and phosphate measurements. Subsamples of $10 \mathrm{ml}$ were taken in polyethylene scintillation vials and were frozen immediately. On land, samples were rapidly thawed and analysed for nitrate $\left(\mathrm{NO}_{3}{ }^{-}\right.$ standard error $0.1 \mu \mathrm{M})+$ nitrite $\left(\mathrm{NO}_{2}^{-}\right.$, standard error $0.02 \mu \mathrm{M})$ and phosphate $\left(\mathrm{PO}_{4}\right.$, standard error $0.02 \mu \mathrm{M}$ ) according to classical methods (respectively Wood et al. 1967, Murphy \& Riley 1962) on an automated Technicon analyser (Tréguer \& Le Corre 1975).

The diffusion of nitrate was calculated according to the formula $F=K_{v} \times \mathrm{d} N / \mathrm{d} z$, where $\mathrm{d} N / \mathrm{d} z$ is the nutrient gradient and $K_{\mathrm{v}}$ is the turbulent diffusion coefficient (Denman \& Gargett 1983). $K_{\mathrm{v}}$ was calculated from $0.25 \times \varepsilon \times$ $\left(1 / N^{2}\right)$, where $N^{2}=(g / \rho \omega) \times(\mathrm{d} \rho / \mathrm{d} z)$ and $\varepsilon$ is the dissipation of the turbulent energy, $N$ is the stratification coefficient, $g$ is the gravitational acceleration, $p \omega$ is the density, and $\mathrm{d} \rho / \mathrm{d} z$ is the density gradient. We used an $\varepsilon$ of $10^{-8} \mathrm{~m}^{2} \mathrm{~s}^{-3}$ (Dillon \& Caldwell 1980), which results in a $K_{v}$ close to the value of $3 \times 10^{-5} \mathrm{~m}^{2} \mathrm{~s}^{-1}$ used in the Mediterranean by Minas \& Codispoti (1993).

Chlorophyll measurements. The total chlorophyll was analysed after filtration of $250 \mathrm{ml}$ subsamples onto Whatman $25 \mathrm{~mm}$ diameter $\mathrm{GF} / \mathrm{F}$ filters, according to the fluorometric 
Table 1. Cruise, date, location, and depth of samples

\begin{tabular}{|c|c|c|c|c|}
\hline $\begin{array}{l}\text { Cruise } \\
\text { Date }\end{array}$ & Station & $\begin{array}{l}\text { Latitude/ } \\
\text { Longitude }\end{array}$ & $\begin{array}{c}\text { Sea } \\
\text { bottom } \\
\text { (m) }\end{array}$ & $\begin{array}{l}\text { Sampling } \\
\text { depths } \\
\text { (m) }\end{array}$ \\
\hline $\begin{array}{l}\text { Picnic } \\
31 \mathrm{Mar}-8 \mathrm{Apr}\end{array}$ & 1 & $\begin{array}{l}43^{\circ} 25.00^{\prime} \mathrm{N} \\
07^{\circ} 25.00^{\prime} \mathrm{E}\end{array}$ & 2200 & $\begin{array}{l}110 \\
230 \\
250\end{array}$ \\
\hline $\begin{array}{l}\text { Dynaproc } \\
11 \text { May - } 1 \text { Jun }\end{array}$ & 1 & $\begin{array}{l}43^{\circ} 25.00^{\prime} \mathrm{N} \\
07^{\circ} 25.00^{\prime} \mathrm{E}\end{array}$ & 2200 & 50 \\
\hline $\begin{array}{l}\text { Rhône } \\
15 \text { May - } 15 \text { Jun }\end{array}$ & Rhône & $\begin{array}{l}43^{\circ} 12.00^{\prime} \mathrm{N} \\
04^{\circ} 57.00^{\prime} \mathrm{E}\end{array}$ & 80 & 10 \\
\hline \multirow[t]{6}{*}{$\begin{array}{l}\text { Euromarge } \\
30 \text { Jun - } 6 \text { Jul }\end{array}$} & S5 & $\begin{array}{l}40^{\circ} 09.50^{\prime} \mathrm{N} \\
03^{\circ} 31.50^{\prime} \mathrm{E}\end{array}$ & 970 & $\begin{array}{r}60 \\
80 \\
190\end{array}$ \\
\hline & S2 & $\begin{array}{l}40^{\circ} 02.00^{\prime} \mathrm{N} \\
03^{\circ} 38.00^{\prime} \mathrm{E}\end{array}$ & 110 & $\begin{array}{r}70 \\
120\end{array}$ \\
\hline & B5 & $\begin{array}{l}42^{\circ} 25.00^{\prime} \mathrm{N} \\
03^{\circ} 04.00^{\prime} \mathrm{E}\end{array}$ & 1000 & $\begin{array}{r}50 \\
80 \\
150\end{array}$ \\
\hline & B2 & $\begin{array}{l}43^{\circ} 34.00^{\prime} \mathrm{N} \\
03^{\circ} 17.00^{\prime} \mathrm{E}\end{array}$ & 88 & $\begin{array}{l}20 \\
40 \\
80\end{array}$ \\
\hline & M3 & $\begin{array}{l}43^{\circ} 02.00^{\prime} \mathrm{N} \\
05^{\circ} 12.50^{\prime} \mathrm{E}\end{array}$ & 950 & $\begin{array}{r}70 \\
90 \\
150\end{array}$ \\
\hline & M1 & $\begin{array}{l}43^{\circ} 10.00^{\prime} \mathrm{N} \\
05^{\circ} 12.50^{\prime} \mathrm{E}\end{array}$ & 85 & $\begin{array}{l}50 \\
80\end{array}$ \\
\hline
\end{tabular}

method of Holm-Hansen \& Riemann (1978) on a Turner Designs 10.005R fluorometer.

Measurement of primary production. Primary production (PP) was measured by in situ ${ }^{14} \mathrm{C}$ (SteemannNielsen 1951) incubation from dawn to dusk (10 to 12 h) with a semi-automated apparatus, 'Let-go' (Dandonneau \& Le Bouteiller 1992, Conan 1996).

At the end of incubation, total introduced radioactivity $\left(\mathrm{dpm}_{\mathrm{l}}\right)$ was measured by placing $250 \mu \mathrm{l}$ of the sample in a polyethylene scintillation vial with $250 \mu \mathrm{l}$ ethanolamine and $1 \mathrm{ml}$ of deionized water. Samples were immediately filtered onto Whatman $25 \mathrm{~mm}$ diameter GF/F filters under low pressure $(<5 \mathrm{~mm} \mathrm{Hg})$, rinsed with the acid solution and dried at $40^{\circ} \mathrm{C}$ for $12 \mathrm{~h}$ and then counted $\left(\mathrm{dpm}_{\mathrm{e}}\right)$ in a Beckman Scintillation Counter after the addition of $5 \mathrm{ml}$ of scintillation solution (Aquasol). The quantity of fixed carbon per hour ( $\mathrm{PP}$ in $\mathrm{mg} \mathrm{C} \mathrm{m}^{-3} \mathrm{~h}^{-1}$ ) was calculated using the formula PP $=\left(\mathrm{dpm}_{\mathrm{e}} / \mathrm{dpm}_{\mathrm{t}}\right) \times\left(V_{p} / V_{f}\right) \times A \times 1.05 \times 1 / t_{\text {, }}$ where $V_{p}$ is the volume of sample taken for determination of total radioactivity, $V_{f}$ is the volume of sample, $A$ is the concentration of carbonates in seawater (about $25000 \mathrm{mg} \mathrm{C} \mathrm{m}^{-3}$ ), 1.05 is the isotopic fractionation between ${ }^{12} \mathrm{C}$ and ${ }^{14} \mathrm{C}$ and $t$ is the incubation time expressed in hours.
Measurement of nitrifying activities. Nitrifying activities were measured on board as soon as the water was collected, from the same Niskin bottle as samples for nutrients analysis. We used the inhibitor method described in Bianchi et al. (1997). Changes in nitrite concentration were measured in subsamples containing either Allylthiourea (ATU) to inhibit ammonia oxidation (Bédard \& Knowles 1989) or $\mathrm{NaClO}_{3}$ to inhibit nitrite oxidation (Hynes \& Knowles 1983, Smorczewski \& Schmidt 1991), thereby allowing the measurement of nitrite and ammonia oxidation, respectively. Each sample was divided into 6 bottles of $1000 \mathrm{ml}$; 2 were blanks, 2 received $10 \mathrm{mg} \mathrm{l}^{-1}$ of ATU and 2 received $10 \mathrm{mM}$ of $\mathrm{NaClO}_{3}$. No substrate $\left(\mathrm{NH}_{4}{ }^{+}\right.$or $\left.\mathrm{NO}_{2}^{-}\right)$was added in order to measure the rates at in situ concentrations of inorganic nitrogen. The bottles were incubated in the dark at in situ temperature. Nitrite concentrations were measured in each flask at $6 \mathrm{~h}$ intervals for $48 \mathrm{~h}$ by a manual colorimetric analysis (Bendschneider \& Robinson 1952) at $543 \mathrm{~nm}$ using $10 \mathrm{~cm}$ pathlength cells which allowed nanomolar determination of the concentration. Calibration curves for the nitrite determination were carried out with 6 standards between 0.01 and $5 \mu \mathrm{M}$, precision $1 \%$. Nitrifying rates were calculated by linear regression from $t_{0}$ to the maximum of increase of $\mathrm{NO}_{2}^{-}$for ammonium oxidation and from $t_{0}$ to the time of substrate $\left(\mathrm{NO}_{2}{ }^{-}\right)$ depletion for nitrite oxidation.

Integrated rates of nitrate production by nitrification were calculated by linear interpolation for Stns B2, M3 and S5. These stations were chosen because nitrification measurements were made at the top of the nitracline and at a depth close to the maximum vertical diffusive flux of nitrate, i.e. 40,90 and $60 \mathrm{~m}$ for Stns B2, $\mathrm{M} 3$ and S5, respectively. The rates were integrated for $20 \mathrm{~m}$ above the depth of measurement assuming that: (1) no more nitrate was produced by nitrification in this layer, and (2) the input of nitrate in the surface layer was rapidly consumed in this $20 \mathrm{~m}$ layer. These assumptions were supported by undetectable concentrations of nitrate when measured by classical analysis, and by negligible rates of nitrification at the top of the considered layer (Figs. 2 \& 3).

\section{RESULTS}

\section{Characterisation of the sampling stations}

For all stations, temperatures corresponding to the same sampling depths were similar (total average $13.61 \pm 0.88^{\circ} \mathrm{C}$ for the 24 samples). Therefore, in spite of the 3 mo delay between the first and last measurements, changes in temperature could not be considered as an influential factor on the measured rates of 


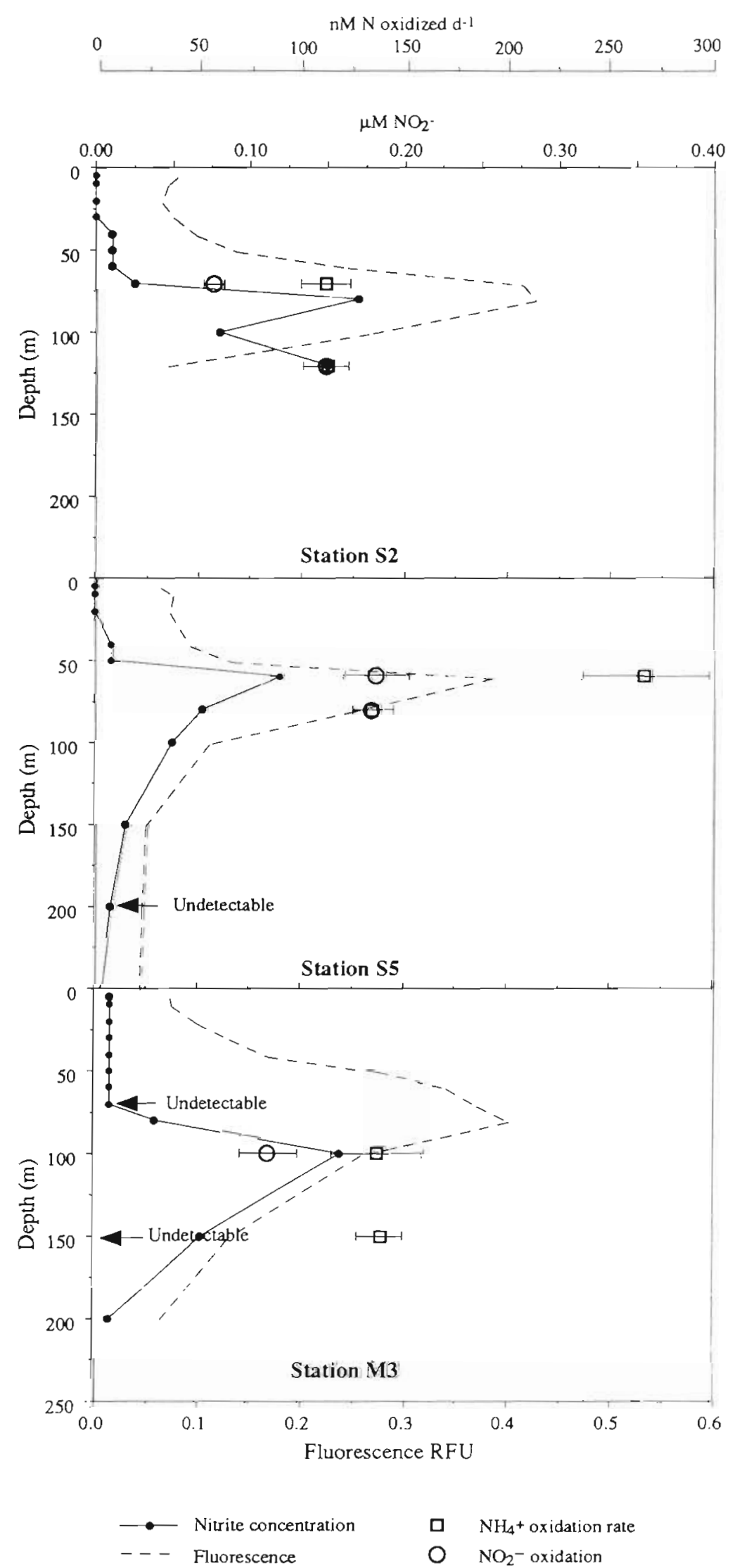

nitrifying activity. Also, the relative in situ fluorescence values were in the same range. For the 24 samples, the average value of fluorescence was $0.49 \mu \mathrm{g} \mathrm{l}^{-1} \pm 0.21$ of chlorophyll, close to the mean value of $0.42 \mu \mathrm{g} \mathrm{l}^{-1}(\mathrm{SD}=0.32, \mathrm{n}=565)$ obtained according to the fluorometric method (Holm-Hansen \& Riemann 1978) during 3 yr of measurements offshore from the city of Marseilles (Conan 1996).

The depth of the peak of fluorescence increased with time, from 10 to $30 \mathrm{~m}$ at Stn 1 in April and May to 50 to $80 \mathrm{~m}$ at Stns M1, M3, B2, B5, S2, S5 at the end of June. The deepening of the peak of chlorophyll corresponded to the depletion of nutrients in the upper layer. Corresponding to the spring situation, primary production was relatively high for the NW Mediterranean, even at the oligotrophic site of the Balearic Islands, the pelagic Stn S5, with a production of $187 \mathrm{mg} \mathrm{C} \mathrm{m} \mathrm{m}^{-2} \mathrm{~d}^{-1}$. The most productive station was Stn 1 in April, with about $1700 \mathrm{mg} \mathrm{C} \mathrm{m}^{-2} \mathrm{~d}^{-1}$, corresponding to values measured during a bloom period (Conan et al. 1998). Simultaneously, the depth of the nitracline was around 10 to $20 \mathrm{~m}$ in April and May, then deepened to 60 to $70 \mathrm{~m}$ in June, as usually observed in this area of the Mediterranean Sea.

\section{Distribution of nitrifying activities}

Taking into account a complete set of data including biogeochemical as well as hydrological data (and not only primary production values), 2 groups of stations were identified in this NW Mediterranean area (Conan et al. 1999). One group of stations was oligotrophic and included Stns S5, S2 and M3, while Stns B2, B5 and M1 belonged to a mesotrophic group. Stn 1 was not considered for this analysis.

Fig. 2. Vertical distribution of in situ fluorescence, nitrite concentration and nitrifying activities in oligotrophic stations (Euromarge cruise). Nitrification rates and nitrite concentrations were measured from the same water samples. Error bars are \pm 1 SE calculated between time zero of 6 nitrite measurements, as in Dore \& Karl (1996). This was the error of the nitrite measure. Undetectable: rate below detection. RFU: relative fluorescence units 
The vertical distributions of nitrifying rates are shown in Figs. 2 \& 3. The highest rates of ammonium oxidation were measured in samples close to the peak of nitrite (identified a posterion of the sampling). With increasing depth, the rates decreased when no nitrite was detected (Stn S5 at $190 \mathrm{~m}$; Fig. 2). When sampling was carried out above the peak of nitrite (Stn B2 at $20 \mathrm{~m}$ and Stn $\mathrm{M} 3$ at $70 \mathrm{~m}$ ) the rates of nitrifying activities were below the detection level. High rates were also measured at the beginning of the nitracline and just above the phosphacline when there was a gap between the nitracline and the phosphacline (Fig. 4, Stn S5). On the other hand, for the samples taken below the nitracline and phosphacline $(200 \mathrm{~m}$ for Stn S5 and $150 \mathrm{~m}$ for Stn B5), no nitrification could be detected with the methodology used.

At Stns S2 and B2 (bottom depth at 110 and $88 \mathrm{~m}$ respectively) nitrite oxidation activities increased with depth (Figs. 2 \& 3 ). In shallow stations, the contribution of the bottom nepheloid layer and/or exchanges with the proximate sediment could provide favourable conditions for nitrifying activities. Organic matter produced in the photic layer can quickly reach the sediment, where it is mineralised and provides substrates for nitrifiers as shown by the increase in nitrite concentration (Figs. $2 \& 3$ ).

In the Ligurian Sea (Stn 1), we sampled at 230 and $250 \mathrm{~m}$ depths in addition to the depth of $110 \mathrm{~m}$ located near the primary nitrite maximum. These depths corresponded to an unexpected deep peak of fluorescence and to concentrations of nitrite fluctuating between 0.159 and $0.335 \mu \mathrm{M}$ (Fig. 5). Moreover, these deep peaks coincided with high nitrifying activities (Fig. 5).

The geographical distribution of the mean values of nitrification rates in the NW basin of the Mediterranean shows that, except for the Rhône River area, these rates ranged from 72

Fig. 3. Vertical distribution of in situ fluorescence, nitrite concentration and nitrifying activities in mesotrophic stations (Euromarge cruise). Nitrification rates and nitrite concentrations were measured from the same water samples. Error bars are \pm 1 SE calculated between time zero of 6 nitrite measurements, as in Dore \& Karl (1996). This was the error of the nitrite measure. Undetectable: rate below detection

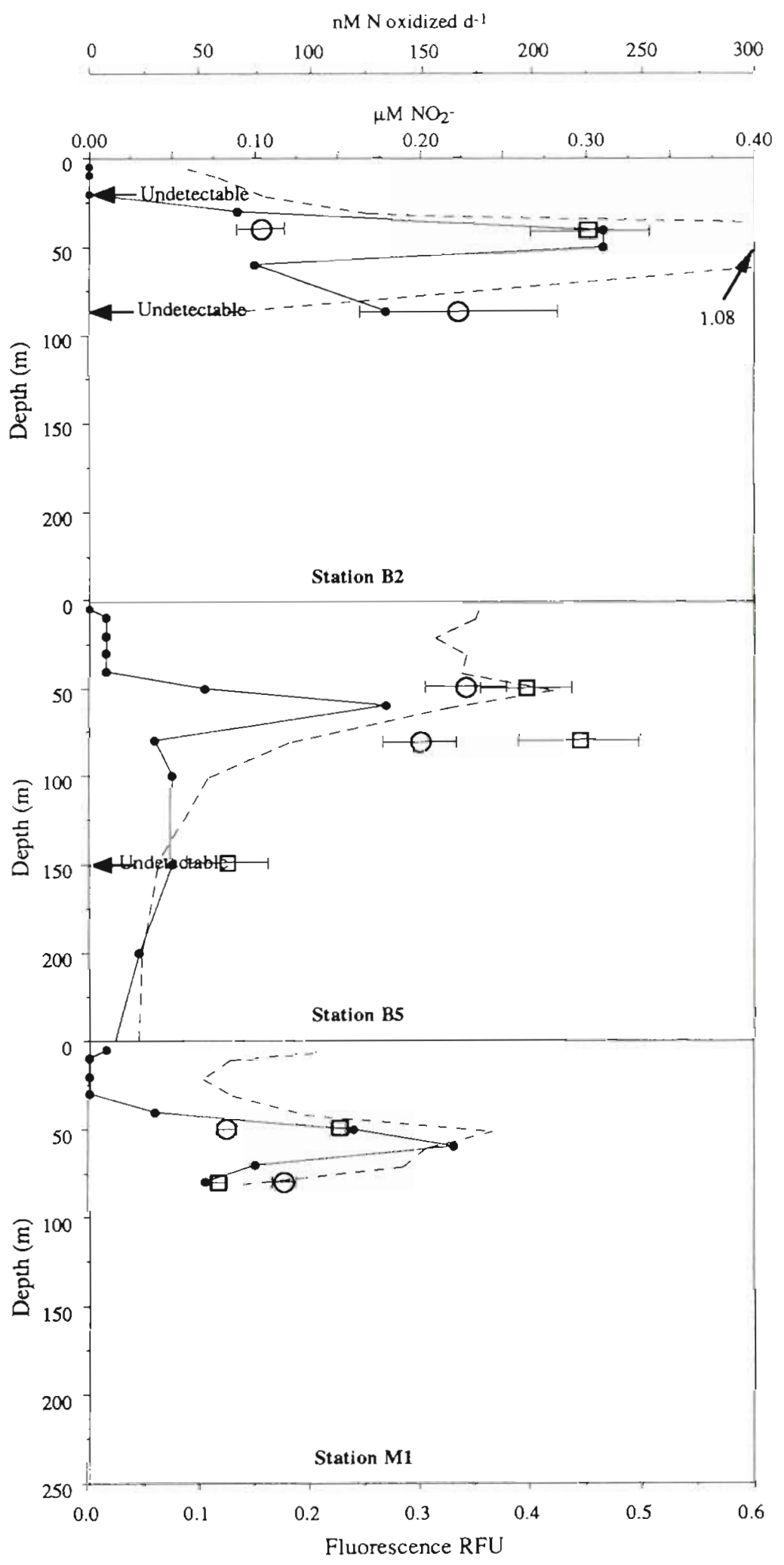




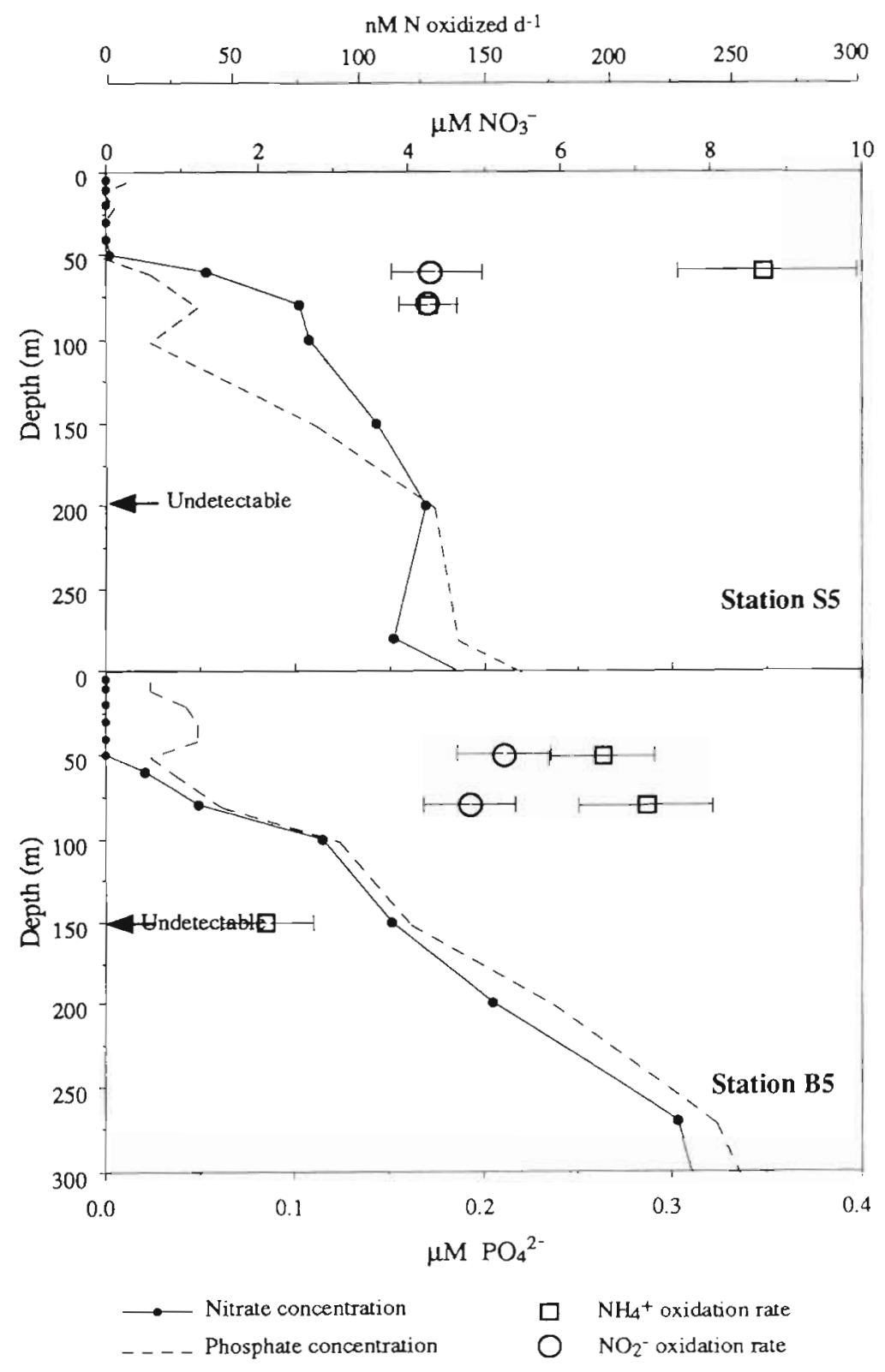

Fig. 4. Example of vertical distribution of nitrifying rates, nitrate and phosphate concentrations (Euromarge cruise). The nitrification rates, nitrite and phosphate concentrations were measured from the same water samples. Error bars are \pm 1 SE calculated between time zero of 6 nitrite measurements, as in Dore \& Karl (1996). This was the error of the nitrite measure Indetertable: rate below detection

to $144 \mathrm{nmol} \mathrm{N}$ oxidised $\mathrm{l}^{-1} \mathrm{~d}^{-1}$. In the vicinity of the Rhone River, the rates increased to 264 and 504 nmol N oxidised $\mathrm{l}^{-1} \mathrm{~d}^{-1}$ because of the direct influence of the riverine inputs of inorganic nitrogen (Feliatra \& Bianchi 1993). These measurements were carried out about $6 \mathrm{~km}$ from the mouth of the river, but the extent of the Rhone River influence on nitrification rates of the Gulf of Lions is still not defined. The highest rates of both ammonium and nitrite oxidation at each station were located between 40 and $70 \mathrm{~m}$ for the coastal stations (Rhône, Stns M1, $\mathrm{B} 2$ and $\mathrm{S} 2$ ) and 60 and 90 to $100 \mathrm{~m}$ for the pelagic stations (Stns 1, M3, B5 and S5) (Figs. 2 to 5).

\section{Short-term fluctuations of nitrifying activities}

The short-term fluctuations of nitrifying activities were measured at Stn 1 during the Dynaproc cruise in May. The method used to measure the nitrifying activities included dark incubation in order to: (1) minimise phytoplankton activity on nutrient concentration, and (2) allow similar conditions of measurement when water samples were collected during the day or during the night.

During the first period, wind stress which occurred on 13 May (wind speed $16 \mathrm{~m} \mathrm{~s}^{-1}$ ) induced mixing in the upper layer, resulting in an increase in nitrate and a decrease in nitrite concentrations (Fig. 6: first period). Ammonium oxidising activity decreased after the wind stress.

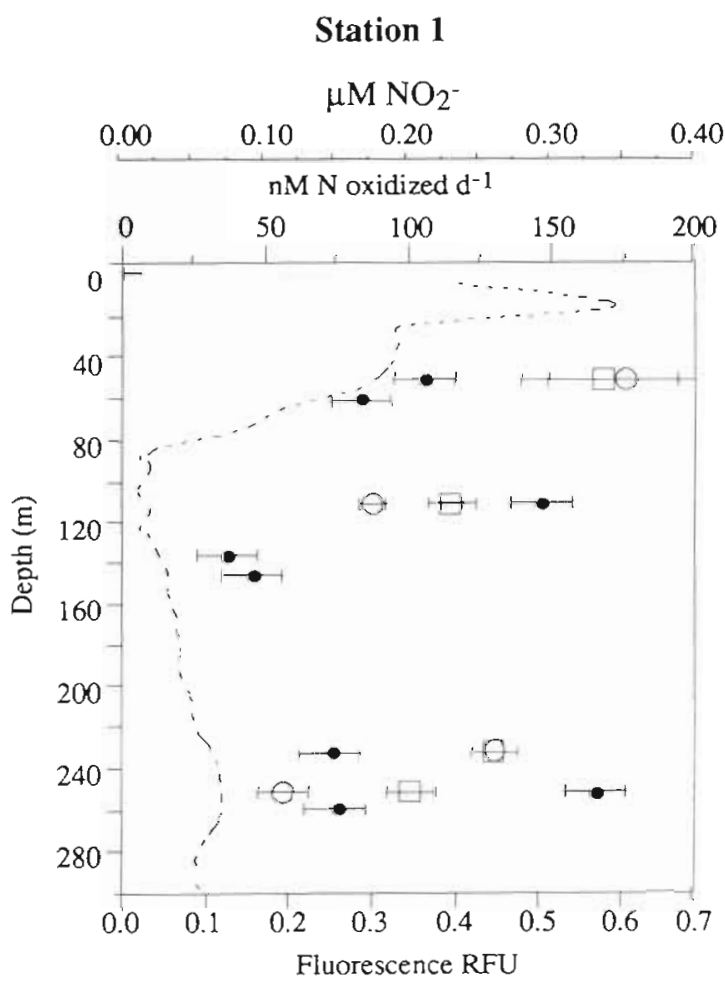

Fluorescence RFU $\square$ Ammonium oxidation rate $\leftrightarrow$ Nitrite concentration $O$ Nitrite oxidation rate

Fig. 5. Vertical distribution of in situ fluorescence, nitrite concentration and nitrifying activities at Stn 1 in the Ligurian Sea (Picnic cruise). Nitrification rates and nitrite concentrations were measured from the same water samples. Error bars are $\pm 1 \mathrm{SE}$ calculated between timezero of 6 nitrite measurements, as in Dore \& Karl (1996). This was the error of the nitrite measure 


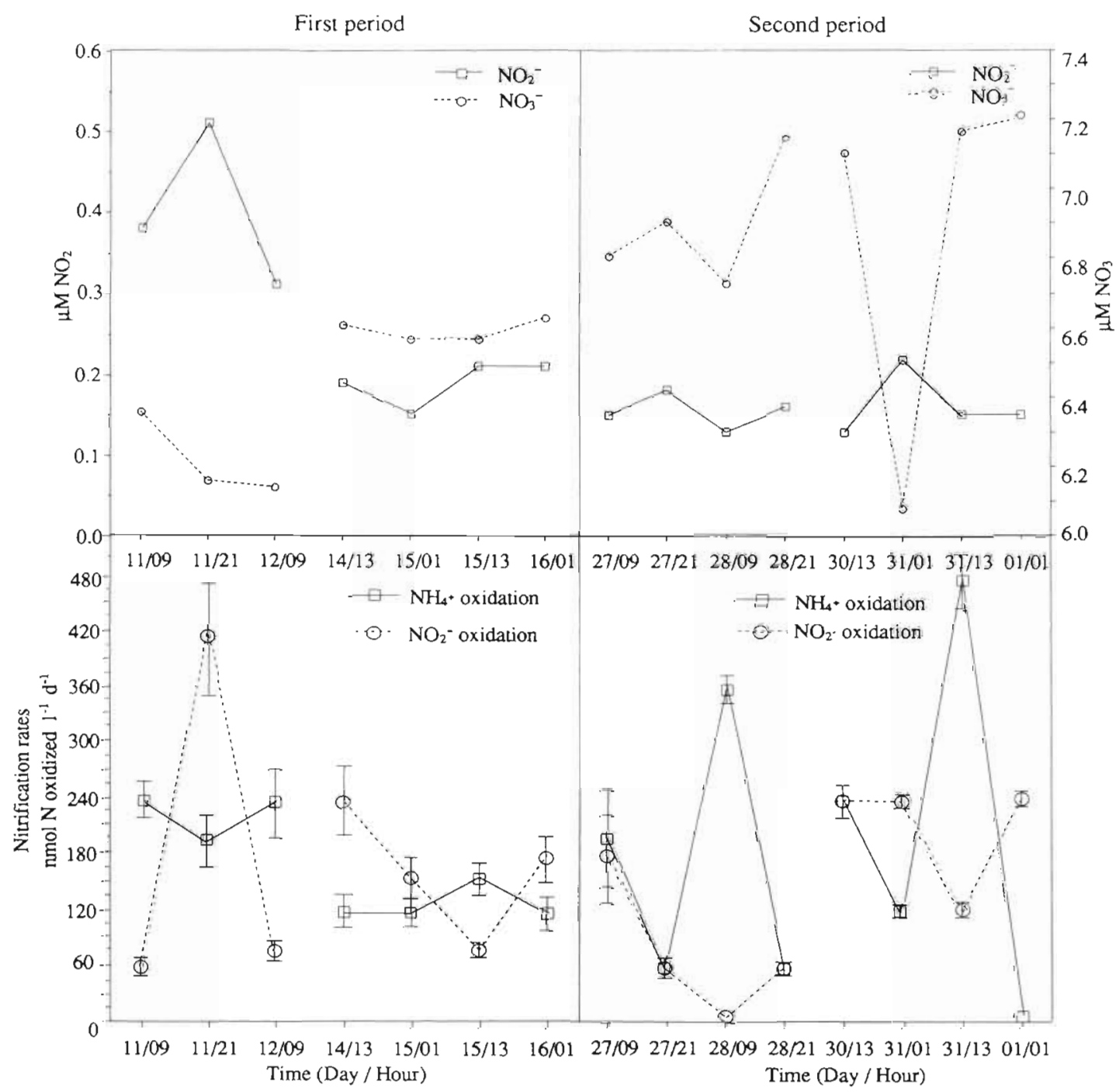

Fig. 6. Short-term fluctuations of the nitrite, nitrate concentrations and ammonium and nitrite oxidation rates at Stn 1 in the Ligurian Sea (Dynaproc cruise). Nitrification rates, nitrite and nitrate concentrations were measured from the same water samples. Error bars are $\pm 1 \mathrm{SE}$ calculated between time zero of 6 nitrite measurements, as in Dore \& Karl (1996). This was the error of the nitrite measure

Rates of ammonium oxidation did not fluctuate significantly within each sub-period (before and after wind stress) and the rates of nitrite oxidation were highly variable (Fig. 6: first period).

During the second period, there was no wind (speed $<6 \mathrm{~m} \mathrm{~s}^{-1}$ ). The nitrate concentrations were higher than during the first period and showed clear fluctuations, while the nitrite concentrations remained at the same values as in the first period (Fig. 6: second period). The rates of ammonium oxidation fluctuated strongly compared to the first period; this point will be discussed later. These ammonium oxidation rates were lower during the night than those of the first period. As shown in Table 2, for all samples collected during the 2 periods, the average values for nitrite oxidation rates were slightly higher and their fluctuations were less significant than ammonium oxidation ones $(n=15 ; p \leq 0.05)$.
Table 2. Average values of ammonium oxidation and nitrite oxidation rates measured during daylight and during the night at Stn 1. Rates are expressed in nmol of $\mathrm{N}$ (ammonium for ammonium oxidation and nitrite for nitrite oxidation) oxidized $\mathrm{l}^{-1} \mathrm{~d}^{-1}$

\begin{tabular}{|lccc|}
\hline Activity & Time & $\begin{array}{c}\text { No. of } \\
\text { samples }\end{array}$ & Mean \pm SD \\
\hline Ammonium & Day & 8 & $218.4 \pm 156$ \\
oxidation & Night & 7 & $96.0 \pm 62.4$ \\
Nitrite & Day & 8 & $153.6 \pm 79.2$ \\
oxidation & Night & 7 & $201.6 \pm 115.2$ \\
Ammonium & Total & 15 & $160.8 \pm 134.4$ \\
oxidation & & 15 & $177.6 \pm 96$ \\
Nitrite & Total & 15 & \\
oxidation & & & \\
\hline
\end{tabular}




\section{DISCUSSION}

In the area of the Mediterranean Sea in which we investigated, the highest nitrification rates occurred around $50 \mathrm{~m}$. Generally, most nitrification occurs near the bottom of the photic zone (Ward et al. 1989). We found the maximum rate of ammonium oxidation at depths near the peak of nitrite, as reported for the Alboran Sea (Bianchi et al. 1994b), in the Algerian current of SW Mediterranean (Gentilhomme \& Raimbault 1994) and in the Pacific and Austral oceans (Olson 1981a, b, Ward 1987). Although our data are sparse, we found the highest rates of nitrification around the nitracline and the phosphacline (Fig. 4). One characteristic of the vertical nutrient profiles during summer in the Mediterranean Sea is a displacement between the nitracline and the phosphacline, which is located 10 to $40 \mathrm{~m}$ deeper (Berland et al. 1988, Conan 1996). This anomaly has also been described in the Pacific Ocean by Bienfang \& Szyper (1981) and in the Atlantic Ocean (Pujo-Pay \& Raimbault 1994). There is currently no satisfactory explanation for such a discrepancy. An increasing uptake of phosphate from the surface to the bottom of the photic layer was noted by Herbland (1984) and Herbland \& Voituriez (1977) in tropical waters.

Unfortunately, phosphate requirements of nitrifying bacteria in natural environments is poorly documented. For pure cultures of Nitrosomonas and Nitrobacter, the optimum phosphate concentrations ranged from 10 to $100 \mathrm{mM}$ (Van Droogenbroeck \& Laudelout 1967). Such concentrations are far from the natural seawater ones. Phosphorus limitation in a nitrification process has been recently described by Nordeidet et al. (1994) in biofilm reactors. If the phosphate requirements of nitrifiers are not negligible, as suggested by their needs in pure culture, we could expect that these bacteria may contribute to the deepening of the phosphacline compared to the nitracline.

The present results show that when samples were taken above the depth of the peak of nitrite (Stn M3, Fig. 2; Stn B2, Fig. 3) the nitrification rates were below a detectable level. Two possible explanations can be evoked for this lack of nitrification in the superficial loyer: (1) an inhibition due to light and/or to rompounds photochemically produced (Horrigan et al. 1981, Olson 1981b, Vanzella et al. 1989), and (2) a lack of ammonium providing energy source for nitrifiers (Olson 1981a, Ward 1985). At Stn 1 (50 m), short-term variations of nitrifying rates were found (Fig. 6). Although the incubations were done in the dark for all samples, fluctuations of nitrifying activities were seen between day and night samples. The average values of ammonium oxidation rates during the day were significantly greater ( $p \leq 0.01$ ), about twice the rates mea- sured during the night (Table 2). Nitrite oxidation rates were slightly, but significantly, higher ( $p \leq 0.01)$ during the night (Table 2). It seems that the 'direct' light effect may not be the major factor implicated in these fluctuations as, at this depth of $50 \mathrm{~m}$, in the Mediterranean Sea, the light intensity was about 0.8 to $1 \%$ of the surface light, corresponding to about 3 to $7 \mathrm{~W} \mathrm{~m}^{-2}$ during the Dynaproc cruise (J. Raunet pers. comm.). Such light intensity is low compared to the value of $50 \mathrm{~W} \mathrm{~m}^{-2}$ cited by Vanzella et al. (1989) as inhibiting ammonium oxidation.

On the other hand, biological processes, with a diurnal cycle, may have played an important role. For example, Van Wambeke et al. (unpubl.) found that bacterial heterotrophic production followed a daynight cycle before the wind stress (11 to 12 May) dur ing the first period and during all of the second period (27 to 28 May and 30 May to 1 June), but not after the wind stress (14 to $16 \mathrm{May}$ ) of the first period. The production of heterotrophic bacteria, which are responsible for mineralisation processes, dropped drastically after this wind-induced mixing. Concomitantly, between 14 and 16 May, ammonium oxidation rates decreased and the fluctuations of nitrifying activities were the lowest. Possibly, the contribution of heterotrophs to the production and the consumption of ammonium decreased. The rapid response of nitrification rates to water mixing suggests a combination of factors, including a shortage of the energetic substrate, i.e. ammonium (Olson 1981a, Ward 1985). In fact, it seems that when the physical processes (wind-induced mixing in our case) were able to overcome the biological processes they induced a levelling (at least apparent) of bacterial processes. Furthermore, depending on the depth of sampling, nitrification rates fluctuated from undetectable to more than $150 \mathrm{nmol} N$ oxidised $\mathrm{I}^{-1} \mathrm{~d}^{-1}$ in $20 \mathrm{~m}$ (Stn M3, Fig. 2; Stn B2, Fig. 3). This variability points out the necessity to multiply, as much as possible, the samples done for one station and, simultaneously, to take into account the hydrological and biological context of the sampling.

In the NW basin, oxidation rates ranged from 72 to $144 \mathrm{nmol} \mathrm{l}^{-1} \mathrm{~d}^{-1}$ at a depth corresponding to the top of the nitracline. Higher rates were reported in previous sturdies for specific areas like the Rhône River plume (4 to 6 times) by Bianchi et al. (1994b) and in the Algerian basin (10 to 90 times) by Gentilhomme \& Raimbault (1994). In both cases, increased concentrations of nutrients were noted, due to riverine inputs in the first case and to vertical advection from the frontal area of the Algerian current in the latter case. At depths greater than $50 \mathrm{~m}$ in the Mediterranean Sea, the temperature of the water column down to the bottom is close to $13^{\circ} \mathrm{C}$ all year round. This typical feature induces a distribution of the nitrification depending mostly on the 
availability of substrate. This could be an explanation for the similar rates measured at diverse pelagic sampling stations during the same season. However, hydrological dynamics can play an important role in the instantaneous rates of nitrification; vertical and/or lateral advection of waters (Conan \& Millot 1995) containing more nutrients or fresh organic matter (PujoPay et al. 1995, Conan 1996) are associated with higher rates.

In most of the cases, at pelagic stations where the sea bottom was deeper than $1000 \mathrm{~m}$ (Stns S5, B5 and M3), both nitrifying activities dropped to below detectable limits when samples were taken below the peak of nitrite. Few measurements of nitrification rates have been performed deeper than 100 to $150 \mathrm{~m}$ in the water column. Detectable rates of ammonium oxidation were measured between 500 and $1000 \mathrm{~m}$ in the tropical North Pacific by Ward \& Zafiriou (1988). In the same oceanic area, Ward (1987), Ward et al. (1989) and Lipschultz et al. (1990) demonstrated that ammonium oxidation decreased sharply from the depth of the primary nitrite maximum to a low and fairly constant rate, while nitrite oxidation rates still demonstrated detectable values and fluctuations deep in the water column.

Deep measurements were carried out at Stn 1 (Ligurian Sea). Rates ranging between 50 to $150 \mathrm{nmol} \mathrm{l}^{-1}$ $\mathrm{d}^{-1}$ coincided with a small peak of fluorescence around $250 \mathrm{~m}$ depth. Such a slight but clear increase of fluorescence suggested the presence of phytoplanktonic cells. The phytoplankton could have come from the surface layer associated with either a particulate flux. or water advection. In the same samples as those used for nitrification measurements, bacterial numbers and heterotrophic activities also peaked (Iriberri et al. 1995, Turley 1995), strengthening the hypothesis that organic matter mineralisation at this depth provided detrital $\mathrm{NH}_{4}{ }^{+}$for nitrification. In all other cases, both nitrifying activities dropped to below a detectable limit in the water column.

Nitrification rates were measured during bloom and transition from bloom to oligotrophy regimes included in the 6 trophic regimes described throughout an annual cycle for the Mediterranean Sea by Lévy et al. (1998). The appearance of the oligotrophic regime was demonstrated by the increasing depth of the chlorophyll maximum from 10 to $30 \mathrm{~m}$ (April) to 50 to $80 \mathrm{~m}$ (end of June), indicating that the surface layer was being depleted of nutrients (Conan 1996). The depth at which the concentration of $\mathrm{NO}_{3}{ }^{-}$was $\geq 1 \mu \mathrm{M}$ increased from 15-25 m (Ligurian Stn 1, April) to more than $70 \mathrm{~m}$ (Balearic site, end of June). The possible contribution of nitrification processes to the in situ concentrations of nitrite and nitrate was estimated. Nitrite produced daily by ammonium oxidation accounted for 30 to $100 \%$ of the nitrite concentration around the nitrite maximum layer. This contribution is higher than the contribution of 10 to $60 \%$ noted by Ward (1987) in oligotrophic waters of the Pacific Ocean. Nitrate produced daily by nitrite oxidation corresponded to $7-20 \%$ of the nitrate concentration at the beginning of the nitracline, a contribution lower than the $33 \%$ measured by Ward (1987). Due to the complexity of interactions between assimilatory and oxidation processes of inorganic nitrogen, particularly in the layer of low light intensity, it is difficult to give typical values for fluxes corresponding to each process.

In the classical distinction between regenerated and new production, the origin of nitrate in the euphotic zone is really essential. The nitrate injected in the surface layer leads to new production, but 'surface in situ recycled nitrate' (i.e. produced by nitrification in the euphotic layer) leads to regenerated production. So, if nitrification is not considered, new production is drastically overestimated from 20 to $100 \%$, as shown by Raimbault et al. (1998) in the equatorial Pacific. In this case, the nitrification has a huge effect on the calculation of the 'f factor', which corresponds to the ratio of new and total production generally estimated using ${ }^{15} \mathrm{~N}$ methods. In order to estimate the contribution of nitrate produced by nitrification to the $\mathrm{N}$ demand of primary producers, an integrated production of nitrate was calculated for Stns B2, M3 and S5 (Table 3). For

Table 3. Contribution of the flux produced by nitrification to the diffusive flux in the nitracline at Stns B2, M3 and S5 of the Euromarge cruise. $K_{\mathrm{y}}$ : turbulent diffusion coefficient

\begin{tabular}{|c|c|c|c|}
\hline $\begin{array}{l}\text { Station: } \\
\text { Depth }(\mathrm{m})^{\mathrm{d}}\end{array}$ & $\begin{array}{c}B 2 \\
20-40\end{array}$ & $\begin{array}{c}M 3 \\
70-90\end{array}$ & $\begin{array}{c}\text { S5 } \\
40-60\end{array}$ \\
\hline $\begin{array}{l}K_{\mathrm{v}}\left(10^{-5} \mathrm{~m}^{2} \mathrm{~s}^{-1}\right) \\
\mathrm{NO}_{3}^{-} \text {diffusion } \\
\left(\mathrm{mmol} \mathrm{m}^{-2} \mathrm{~d}^{-1}\right)\end{array}$ & $\begin{array}{c}3.0 \\
0.443\end{array}$ & $\begin{array}{c}5.3 \\
0.363\end{array}$ & $\begin{array}{c}2.2 \\
0.119\end{array}$ \\
\hline 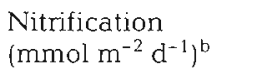 & 0.82 & 1.3 & 1.44 \\
\hline $\begin{array}{l}\text { Primary production } \\
\left(\mathrm{mg} \mathrm{C} \mathrm{m}^{-2} \mathrm{~d}^{-1}\right)\end{array}$ & $\begin{array}{c}\text { (for } 5-40 \mathrm{~m} \text { ) } \\
\quad 406\end{array}$ & $\begin{array}{c}\text { (for } 5-90 \mathrm{~m} \text { ) } \\
377\end{array}$ & $\begin{array}{c}\text { (for } 5-60 \mathrm{~m} \text { ) } \\
187\end{array}$ \\
\hline $\begin{array}{l}\text { Corresponding } \\
\mathrm{N} \text { demand } \\
\left(\mathrm{mmol} \mathrm{m}^{2} \mathrm{~d}^{i}\right)^{c}\end{array}$ & 5.13 & 4.76 & 2.36 \\
\hline $\begin{array}{l}\text { Contribution of } \\
\mathrm{NO}_{3}{ }^{-} \text {diffusion to } \\
\text { the } \mathrm{N} \text { demand }(\%)\end{array}$ & 9 & 8 & 5 \\
\hline $\begin{array}{l}\text { Contribution of } \\
\text { nitrification to } \\
\text { the N demand }(\%)\end{array}$ & 16 & 27 & 61 \\
\hline \multicolumn{4}{|c|}{$\begin{array}{l}{ }^{\mathrm{a}} \mathrm{Depths} \text { of integration for } \mathrm{NO}_{3}{ }^{-} \text {diffusion and integrated } \\
\text { nitrification calculations } \\
\text { } \mathrm{NO}_{3}^{-} \text {produced by nitrification for the corresponding layer } \\
{ }^{C} \mathrm{Calculated} \text { using }{ }^{14} \mathrm{C} \text { estimation and } \mathrm{C} / \mathrm{N}=6.6\end{array}$} \\
\hline
\end{tabular}


nitrifying activities, we were not able to carry out the measurements every $10 \mathrm{~m}$, as was done for the determination of nitrogen compounds, and the sampling depths for measurements of nitrification were decided by considering the bottom of the peak of fluorescence determined in real time by CTD casts. Therefore, only for Stns B2, M3 and S5, all parameters (primary production, $N$ demand and nitrate diffusion) were available at the same depth as nitrification rates. Primary production increased from Stn $\mathrm{S} 5$ (187 $\mathrm{mg} \mathrm{C} \mathrm{m}^{-2} \mathrm{~d}^{-1}$ ), to Stn $\mathrm{M} 3$ (377 $\mathrm{mg} \mathrm{C} \mathrm{m}^{-2} \mathrm{~d}^{-1}$ ) through to Stn B2 (406 mg $\mathrm{C} \mathrm{m}^{-2} \mathrm{~d}^{-1}$ ), revealing a trophic gradient (Table 3 ). The vertical flux of nitrate estimated at the base of the photic layer followed the same pattern $10.119,0.363$ and $0.443 \mathrm{nmol} \mathrm{m}^{-2} \mathrm{~d}^{-1}$, for Stns S5, M3 and B2 respectively), so too did the contribution of the diffusive process, increasing from 5 (Stn S5) to 9\% (Stn B2). Such calculations do not take into account the input by advection (Conan et al. 1999) and 'pulses' (Klein \& Coste 1984). Conversely, nitrate production by nitrification increased from Stns B2 to M3 and S5 (Table 3). As a consequence, the calculated contribution of nitrification to the $\mathrm{N}$ demand in the surface layer was $16 \%$ at $\operatorname{Stn} \mathrm{B} 2$, but reached $61 \%$ at the most oligotrophic station, Stn S5 (Table 3).

The highest contribution of nitrification to the $N$ demand $(61 \%)$ was measured in the most oligotrophic station, although this value was lower than those published by Dore \& Karl (1996), who estimated a contribution of the nitrification to the gross nitrate + nitrite assimilation rate from 47 to $142 \%$ for the oligotrophic Stn ALOHA, a North Pacific deep water site. In addition, in the Pacific Ocean, Raimbault et al. (1998) showed an overestimation of 20 to $100 \%$ of the new production when nitrification was not taken into account. In less oligotrophic areas, such as Stn M3, the contribution of nitrate regenerated by nitrification was $27 \%$. This value is close to fluxes of regenerated nitrate from nitrification $(23 \%$ of the nitrogen assimilated at the chlorophyll maximum) established by Gentilhomme (1992) in the Algerian Basin, which shows high concentrations of chlorophyll. At the eastern boundary of the Alboran Sea (eastern area of the Gibraltar Strait), a possible contribution of about $40 \%$ of the nitrate produced by nitrification was calculated in the surface Atlantic water for which the nitrite concentrations were high $(>0.20 \mu \mathrm{M})$ and the nitracline was around $60 \mathrm{~m}$ (Bianchi et al. 1994b).

In the NW Mediterranean basin, the distribution of nitrifying activity displays a patchiness similar to that of trophic richness. In the Rhône River plume area, due to inputs of ammonium by the river waters, the rates of nitrification were the highest of the zone. Previously, Bianchi et al. (1994a) estimated that 15\% of the allochthonous $\mathrm{NH}_{4}{ }^{+}$was nitrified in the plume area, contributing to the nitrate enrichment of the surrounding marine waters. In pelagic areas, far from the influence of the Rhone River, the flux of nitrate originating from nitrification showed an increasing contribution to nitrate uptake by primary producers as the oligotrophy increased, from 25 to $30 \%$ in mesotrophic areas like the Gulf of Lions in the north and the Algerian current or the Alboran Sea in the south to more than $60 \%$ in the very oligotrophic site of the Balearic Islands.

Acknowledgements. The 2 cruises Picnic (EMPS project cruise, cruise leader M.B., RV 'Tethys II') and Euromarge (cruise leader X. Durrieu de Madron, RV 'Le Suroît') were organised within the Mediterranean Targeted Project. The Dynaproc cruise (cruise leader V. Andersen, RV 'Le Suroitt') was performed within the French programme DYFAMED. We are grateful to $M$. Picheral, L. Steeman, G. Gorsky, V. Martin and $X$. Durrieu de Madron, who carried out CTD measurements. We are pleased to thank Dr Carol Phillips for helpful comments and correction of the English language. We also express our thanks to the anumymous reviewers, as well as to Dr John Dolan, for their comments and corrections. This research has been undertaken in the framework of the Mediterranean Targeted Project (MTP) - EMPS project. We acknowledge the support from the European Commission's Marine Science and Technology (MAST) Programme under contract MAS2-CT94-0090.

\section{LITERATURE CITED}

Andersen V, Baker M, Nival P (1990) Vertical flux of matter from the upper layer of the sea. Abstracts of JGOFS/IGBP meeting on modelling the physics, biology and chemistry of the upper ocean, and its interaction with the atmosphere, 12-13 March 1990. Book of Abstracts, London

Bédard C, Knowles R (1989) Physiology, biochemistry, and specific inhibitors of $\mathrm{CH}_{4}, \mathrm{NH}_{4}^{+}$, and $\mathrm{CO}$ oxidation by methanotrophs and nitrifiers. Microbiol Rev 53:68-84

Bendschneider K, Robinson RJ (1952) A new spectrophotometric method for the determination of nitrite in seawater. J Mar Res 11:87-96

Berland BR, Bonin DJ, Maestrini SY (1980) Azote ou phosphore? Considérations sur le paradoxe nutritionnel de la Mer Méditerranée. Oceanol Acta 3:135-142

Berland BR, Benzhitsky AG, Burlakova ZP, Georgieva LV, Izmestiev AMA, Kholodov VY, Maestrini SY (1988) Conditions hydrologiques estivales en Méditerranée, répartition du phytoplancton et de la matière organique. In: Minas $\mathrm{HJ}$, Nival P (eds) Océanographie pélagique méditerranéenne. Oceanol Acta 1, No. Spec 9:163-179

Bethoux JP, Morin P, Madec C, Gentili B (1992) Phosphorus and nitrogen behaviour in the Mediterranean Sea. DeepSea Res 39:1641-1654

Bianchi M, Bonin P. Feliatra (1994a) Bacterial nitrification and denitrification rates in the Rhône River plume (northwestern Mediterranean Sea). Mar Ecol Prog Ser 103:197-202

Bianchi M, Morin P, Le Corre P (1994b) Nitrification rates, nitrite and nitrate distribution in the Almeria-Oran frontal systems (eastern Alboran Sea). J Mar Syst 5:327-342

Bianchi M, Feliatra, Tréguer $\mathrm{P}$, Vincendeau MA, Morvan J (1997) Nitrification rates, ammonium and nitrate distribution in upper layers of the water column and in sediments of the Indian sector of the Southern Ocean. Deep-Sea Res $44: 1017-1032$ 
Bienfang PK, Szyper JP (1981) Phytoplankton dynamics in the subtropical Pacific Ocean off Hawaii. Deep-Sea Res 28A (9):981-1000

Conan P (1996) Variabilité et bilan de la production primaire en zone côtière (Méditerranée Nord occidentale, entrée du golfe du Lion) en relation avec les systèmes biologique, chimique et hydrodynamique (Courant Nord Méditerranéen). Thèse de l'Université de la Méditerranée, AixMarseille II

Conan P, Millot C (1995) Variability of the Northern Current in the Western Mediterranean Sea from February to June 1992. Oceanol Acta 18:193--205

Conan P, Pujo-Pay M, Raimbault P, Leveau M (1998) Variabilité hydrologique et biologique au sein du Courant Nord Méditerranéen à l'entrée du golfe du Lion. I. Bilan annuel des transports en azote et productivité potentielle. Oceanol Acta 21:751-765

Conan P. Turley C, Stutt E, Pujo-Pay M, Van Wambeke F (1999) Relationship between phytoplankton efficiency and the proportion of bacterial production to primary production in the Mediterranean Sea. Aquat Microb Ecol 17: 131-144

Coste B, Le Corre P, Minas HJ (1988) Re-evaluation of the nutrient exchanges in the Straits of Gibraltar. Deep-Sea Res 35:767-775

Cruzado A, Velasquez ZR (1990) Nutrients and phytoplankton in the Gulf of Lions, northwestern Mediterranean. Cont Shelf Res 10:931-942

Dandonneau Y, Le Bouteiller A (1992) A simple and rapid device for measuring planktonic primary production by in situ sampling, and ${ }^{14} \mathrm{C}$ injection and incubation. Deep-Sea Res 39:795-803

Denman KL, Gargett AE (1983) Time and space scales of vertical mixing and advection of phytoplankton in the upper ocean. Limnol Oceanogr 28:801-815

Dillon TM, Caldwell DR (1980) The batchaloo spectrum and dissipation in the upper ocean spectrum. J Geophys Res 87:9601-9613

Dore JE, Karl DM (1996) Nitrification in the euphotic zone as a source for nitrite, nitrate, and nitrous oxide at Station ALOHA. Limnol Oceanogr 41:1619-1628

Dugdale RC, Goering JJ (1967) Uptake of new and regenerated forms of nitrogen in primary productivity. Limnol Oceanogr 12:196-206

Feliatra, Bianchi M (1993) Rates of nitrification and carbon uptake in the Rhône river plume (Northwestern Mediterranean Sea). Microb Ecol 26:21-28

Gentilhomme V (1992) Quantification des flux d'absorption et de régénération de l'azote minéral (nitrate, nitrite, ammonium) et organique (urée) dans la couche euphotique des océans oligotrophes. Thèse de l'Université Aix-Marseille II

Gentilhomme V, Raimbault $P$ (1994) Absorption et régénération de l'azote dans la zone frontale du courant Algérien (Méditerranée Occidentale): reévaluation de la production nouvelle. Oceanol Acta 17:555-562

Herbland A (1984) Phosphate uptake in the euphotic layer of the Equatorial Atlantic Ocean. Methodological observations and ecological significance. Océanogr Trop 19:25-40

Herbland A, Voituriez B (1977) Production primaire, nitrate et nitrite dans l'Atlantique tropical. I-Distribution du nitrate et production primaire. Cah ORSTOM Ser Océanogr 15:47-55

Holm-Hansen O, Riemann B (1978) Chlorophyll a determination: improvements in methodology. Oikos 30:438-447

Horrigan SG, Carlucci AF, Williams PM (1981) Light inhibition of nitrification in sea surface films. J Mar Res 39:151-166
Hynes RK, Knowles R (1983) Inhibition of chemoautotrophic nitrification by sodium chlorate and sodium chlorite: a reexamination. Appl Environ Microbiol 45:1178-1182

Iriberri J, Unanue M, Ayo B (1995) Heterotrophic activity and glucose uptake and mineralization. In: Bianchi $M$ (ed) Mediterranean Targeted Project, European Microbiology of Particulate Systems (MTP-EMPS) project first annual report, Partner no. 4. EC Contract MAS2-CT94-0090, Marseille

Jacques G (1989) L'oligotrophie du milieu pélagique de Méditerranée Occidentale: 'un paradigme qui s'estompe?'. Bull Soc Zool Fr 114:18-30

Klein P, Coste B (1984) Effects of wind stress variability on nutrient transport into the mixed layer. Deep-Sea Res 31. 21-27

Lévy M, Mémery L, André JM (1998) Simulation of primary production and export fluxes in the NW Mediterranean Sea. J Mar Res 56:197-238

Lipschultz F, Wofsy SC, Ward BB, Codispoti LA, Friedrich G, Elkins JW (1990) Bacterial transformations of inorganic nitrogen in the oxygen-deficient waters of the Eastern Tropical South Pacific Ocean. Deep-Sea Res 37: 1513-1541

Minas HJ, Codispoti LA (1993) Estimation of primary production by observation of changes in the mesoscale nitrate field. ICES Mar Sci Symp 197:215-235

Minas HJ, Minas $M$, Coste B, Gostan J, Nival P, Bonin D (1988) Production de base et de recyclage; une revue de la problématique en Méditerranée Nord-Occidentale. Oceanol Acta 9:155-162

Murphy J, Riley JP (1962) A modified single solution method for determination of phosphate in natural waters. Anal Chim Acta 27:31-36

Nordeidet B, Rusten B, Odegaard H (1994) Phosphorus requirements for tertiary nitrification in a biofilm. Water Sci Technol 29:77-82

Olson RJ (1981a) ${ }^{15} \mathrm{~N}$ tracer studies of the primary nitrite maximum. J Mar Res 39:203-226

Olson RJ (1981b) Differential photoinhibition of nitrifying bacteria: a possible mechanism for the formation of the primary nitrite maximum. J Mar Res 39:227-228

Pujo-Pay M, Raimbault P (1994) Etude de la relation nitrate / phosphate dans la recherche du facteur nutritionnel limitant des eaux de l'Atlantique tropical. I Rech Océanogr 19:150-156

Pujo-Pay M, Conan P, Raimbault P (1995) Particulate and dissolved organic nitrogen and phosphorus in the northwestern Mediterranean Sea (Eros 2000-Discovery cruise 1993). In: Martin JM, Barth $\mathrm{H}$ (eds) Water pollution research reports, 'EROS 2000', Vol 32. European Commission, Luxembourg, p 79-86

Raimbault P, Slawyk G, Boudjellal B, Coatanoan C, Conan P, Coste B, Garcia N, Moutin T, Pujo-Pay M (1998) Carbon and nitrogen uptake and export in the equatorial Pacific at $150^{\circ} \mathrm{W}$ : evidence of an efficient regenerated production cycle. J Geophys Res 104:3341-3356

Smorczewski WT, Schmidt EL (1991) Numbers, activities, and diversity of autotrophic ammonia-oxidizing bacteria in freshwater, eutrophic lake sediment. Can J Microbiol 37: 828-833

Steemann-Nielsen E (1951) Measurement of the production of the organic matter in the sea by mean of carbon 14 Nature 167:684-685

Turley C (1995) Bacterial biomass and production. In: Bianchi $M$ (ed) Mediterranean Targeted Project, European Microbiology of Particulate Systems (MTP-EMPS) project first annual report, Partner no. 5. EC Contract MAS2-CT94- 
0090, Marseille

Tréguer P, Le Corre P (1975) Manuel d'analyse des éléments nutritifs dans l'eau de mer (utilisation de l'autoanalyseur II Technicon). Université Bretagne Occidentale, Brest

Van Droogenbroeck $R$, Laudelout $H$ (1967) Phosphate requirements of the nitrifying bacteria. Antonie Leeuwenhoek 33:287-296

Vanzella A, Guerrero MA, Jones RD (1989) Effect of CO and light on ammonium and nitrite oxidation by chemolithotrophic bacteria. Mar Ecol Prog Ser 57:69-76

Ward BB (1985) Light and substrate concentration relationships with ammonium assimilation and oxidation rates.

Editorial responsibility: John Dolan,

Villefranche-sur-Mer, France
Mar Chem 16:301-316

Ward BB (1987) Nitrogen transformations in the Southern California Bight. Deep-Sea Res 34:785-805

Ward BB, Zafiriou OC (1988) Nitrification and nitric oxide in the oxygen minimum of the eastern tropical North Pacific. Deep-Sea Res 35:1127-1142

Ward BB, Kilpatrick KA, Renger EH, Eppley RW (1989) Biological nitrogen cycling in the nitracline. Limnol Oceanogr $34: 496-513$

Wood EPK, Armstrong FAJ, Richards FA (1967) Determination of nitrate in seawater by cadmium copper reduction to nitrite. J Mar Biol Assoc UK 47:23-31

Submitted: February 24, 1998; Accepted: October 29, 1998 Proofs received from author(s): May 31, 1999 